\title{
Probing behavior of Dysmicoccus brevipes mealybug in pineapple plants ${ }^{1}$
}

\author{
Lenira Viana Costa Santa-Cecília², Ernesto Prado², Brígida Souza ${ }^{3}$
}

\section{ABSTRACT}

Differences in susceptibility to viruses in plants may be partially explained by the insect vector probing behavior and by the presence of phenolic compounds, which are often associated with defense strategies. This study aimed at detecting barriers that may difficult the probing activity of the Dysmicoccus brevipes (Pseudococcidae) pineapple mealybug, a vector of the pineapple mealybug wilt-associated virus, as well as evaluating the phenolic content of plants, in order to verify any possible relationship with the probing behavior, by using the electrical penetration graphs (EPG) technique. Seedlings of 'Smooth Cayenne' and 'Pérola' pineapple cultivars were used in the experiments. Only $28 \%$ and $21 \%$ of the mealybugs reached the phloem of the 'Smooth Cayenne' and 'Pérola' cultivars, respectively, over $16 \mathrm{~h}$ of recording, with an average of $9 \mathrm{~h}$ to reach the phloem vessels. The xylem phase was extended in both cultivars and represented approximately $31 \%$ ('Smooth Cayenne') and $44 \%$ ('Pérola') of the recording time. The phenolic contents of both cultivars were similar.

KEYWORDS: Ananas comosus; pineapple mealybug; phenols.

\section{INTRODUCTION}

The pineapple mealybug [Dysmicoccus brevipes (Cockerell) (Hemiptera: Pseudococcidae)] is a significant limiting factor for the pineapple production, as it restricts the expansion of cultivated areas and reduces plant yield (Santa-Cecília et al. 2004). Sap-sucking mealybugs weaken plants directly, but, more importantly, they are major vectors of the pineapple mealybug wilt-associated virus (PMWaV) (Gunashinghe \& German 1989, Setter et al. 1998). Particles of this virus are primarily restricted to the phloem, from where they are acquired by vectors.

PMWaV, which belongs to the Ampelovirus genus (Closteriviridae family), is semi-persistently

\section{RESUMO}

Conduta alimentar da cochonilha Dysmicoccus brevipes em abacaxizeiro

Diferenças de suscetibilidade a viroses em plantas podem ser parcialmente explicadas pelo comportamento alimentar dos insetos vetores e presença de fenóis, a qual tem sido, muitas vezes, relacionada com tais defesas. Objetivou-se detectar barreiras que dificultem a alimentação da cochonilha Dysmicoccus brevipes (Pseudococcidae), vetora do vírus pineapple mealybug wilt-associated em abacaxizeiro, bem como analisar o conteúdo de fenóis dessas plantas, a fim de verificar a possível existência de correlação com a conduta alimentar, por meio da técnica de Electrical Penetration Graphs (EPG). Utilizaram-se as cultivares 'Smooth Cayenne' e 'Pérola'. Somente $28 \%$ e $21 \%$ das cochonilhas atingiram o floema nas cultivares 'Smooth Cayenne' e 'Pérola', respectivamente, durante as $16 \mathrm{~h}$ de registro, e, em média, levaram $9 \mathrm{~h}$ para alcançar os vasos floemáticos. A fase no xilema foi extensa em ambas as cultivares e representou, aproximadamente, $31 \%$ ('Smooth Cayenne') e $44 \%$ ('Pérola') do tempo registrado. $\mathrm{O}$ conteúdo de fenóis não diferiu entre as cultivares.

PALAVRAS-CHAVE: Ananas comosus; cochonilha-do-abacaxi; fenóis.

transmitted via mealybug saliva, during the stylet penetration (Jahn et al. 2003). Although the underlying mechanisms of how this semi-persistent virus is acquired and inoculated are not well understood, phloem-sap feeding seems to be an essential step in the transmission process (Moreno et al. 2012). Consequently, individual plants or cultivars that exhibit resistance to phloem-sap feeding should be, theoretically, less susceptible to infection.

The mealybug wilt disease occurs in several regions where pineapple is cultivated, in Brazil, and accounts for up to $80 \%$ of the yield losses of this crop (Sanches 2005). The 'Smooth Cayenne' pineapple cultivar has been reported to be highly susceptible to both mealybug infestation and PMWaV. Conversely,

1. Manuscript received in Jul./2016 and accepted for publication in Dec./2016 (http://dx.doi.org/10.1590/1983-40632016v4642278).

2. Empresa de Pesquisa Agropecuária de Minas Gerais, Lavras, MG, Brazil. E-mails: scecilia@epamig.ufla.br, epradoster@gmail.com. 3. Universidade Federal de Lavras, Departamento de Entomologia, Lavras, MG, Brazil. E-mail: brgsouza@den.ufla.br. 
the 'Perola' cultivar is moderately tolerant, with lower yield losses (Giacomelli \& Py 1981, Matos \& Reinhardt 2009).

The reproductive success of sap-sucking insects is highly dependent on their ability to bypass or neutralize plant defenses they encounter in the cuticle, epidermal and mesophyll tissues of plants, as well as in the phloem in which they feed. These barriers, whether physical or chemical, may restrict the probing behavior of mealybugs, contributing to viral-transmission resistance.

The pathway of a stylet through the tissues of a plant can be observed with an electrical penetration graph (EPG) (Tjallingii 1978), a technique in which waveforms and patterns produced by stylet penetrating are associated with determined events and stylet location, which are in turn related to host selection. This technique has been previously used to study the probing behavior of several sucking insects (Calatayud et al. 1994, Kindt et al. 2006, Miranda et al. 2009, Cid \& Fereres 2010, Lazzarotto et al. 2011, Liu et al. 2013, Moraes et al. 2013, Santa-Cecília et al. 2013), plant resistance (Crompton \& Ode 2010) and viral transmission (Tjallingii \& Prado 2001, Fereres \& Moreno 2009).

Herbivorous insects face numerous physical and chemical barriers, when attempting to feed on plants. For example, plant cells often contain toxic compounds that can deter the insect probing behavior and, therefore, be used as a defense against pathogens (Miles \& Oertli 1993). Calatayud et al. (1994), for instance, reported that phenols produced by cassava cultivars alter the probing behavior of the cassava mealybug (Phenacoccus manihoti MatileFerrero).

This study aimed at identifying possible constraints to stylet penetration in pineapple cultivars, as a way of explaining the differences in susceptibility between them, and determining whether phenolic concentrations differ between these cultivars.

\section{MATERIAL AND METHODS}

Mealybugs used in this study were reared from insects collected from pineapple [Ananas comosus (L.) Merrill, cv. Smooth Cayenne], in Piumhí $\left(20^{\circ} 27^{\prime} 42^{\prime \prime} \mathrm{S}, 45^{\circ} 56^{\prime} 45^{\prime \prime} \mathrm{W}\right)$, Minas Gerais State, Brazil, and maintained on the same cultivar in a greenhouse, at the Universidade Federal de
Lavras, also in the Minas Gerais State, from January to October 2012.

The 'Smooth Cayenne' and 'Pérola' pineapple cultivars were used because of their different levels of susceptibility to the mealybug wilt disease. No signals were found when the EPG technique was preliminary conducted on 6-month-old pineapple plants. However, plants produced via in vitro tissue cultures displayed clear signals and were thus selected for the EPG tests. Four-leaf pineapple plants used in the experiment were kept in 50-ml glass containers filled with water.

In the EPG, the mealybug is part of a circuit through which a small amount of current, in the form of adjustable plant voltage, is applied. The mealybug resistance to the current and electromotive forces are visualized as voltage fluctuations, and different waveforms are related to specific biological events, such as stylet sheath formation, salivation, phloemsap ingestion, etc. A schematic diagram of the EPG circuit is presented in Figure 1.

Recordings of the EPG circuit were made with a Giga8 device connected to amplifiers $\left(10^{9} \Omega\right.$ input resistance and 50x gain). Signals were analyzed using the Stylet 3.0 software (Giga8 manufacturer and software supplier, EPG systems, Dillenburg 12, 6703 CJ Wageningen, The Netherlands). Analog signals were converted to digital with a DAS-800 A/D card (Keithley Metrabyte Corp.).

Mature female mealybugs with an age of up to five days after final molt were used in the experiments. Mealybugs were starved for $1 \mathrm{~h}$ prior to the initiation of the EPG recording, and the wax covering the mealybug dorsum was removed with a fine humid brush. Afterwards, a 2-cm long and $20-\mu \mathrm{m}$ diameter gold wire was glued to the dorsum by means of silver paint. Mealybugs were then connected to the amplifier and placed on a leaf, with a second electrode

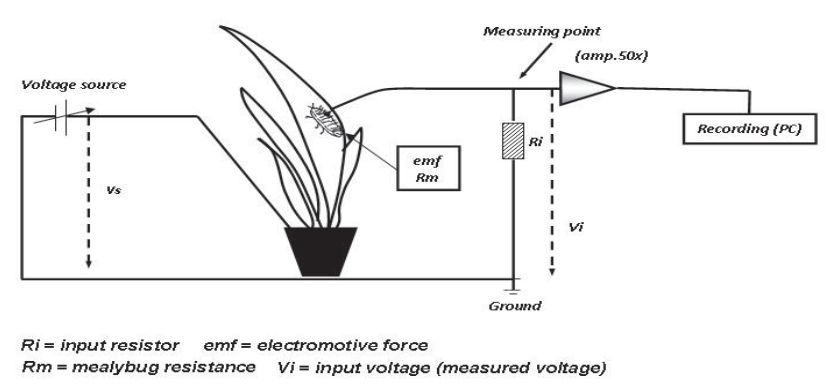

Figure 1. Schematic diagram of the EPG circuit (modified from Tjallingii 2000). 
immersed in the water contained inside the pot. The complete set-up was installed inside a Faraday cage. The circuit was closed when a mealybug inserted its stylet into a plant, and the signal was recorded as waveforms and patterns.

Treatments consisted of the 'Smooth Cayenne' and 'Pérola' cultivars, with 24 replicates, using 24 plants of each cultivar and one insect by plant. Each recorded insect was considered to be one experimental unit, and recordings lasted for $16 \mathrm{~h}$. Eight insects were simultaneously monitored on eight channels of the EPG monitor, four of each cultivar, and randomly connected to the signals amplifier of the equipment. Four-leaf pineapple plants used in the experiment were kept in 50-ml glass containers filled with water.

Waveforms and patterns were classified according to the system described by Calatayud et al. (1994), Santa-Cecília (2003) and Cid \& Fereres (2010). Probing behaviors consisted of 62 parameters related to feeding events, but only those considered relevant to the specific objectives of this research are presented here: number of probes, non-probing time, time to the first probe, pathway phase (pattern "C"), xylem phase (pattern "G"), pathway + xylem phase, mealybugs showing phloem phase, phloem phase (pattern "E"), time to reach the phloem phase from the first probe, time to reach the phloem phase in the probe and hours until the phloem is reached.

Polyphenol concentrations of the pineapple plants used for the EPG were extracted using the methodology described by Goldstein \& Swain (1963) and estimated according to the Folin Denis method
(AOAC 1990). Approximately $1 \mathrm{~g}$ of dry milled leaves was used for the analysis, with methanol serving as the solvent in three successive times. A spectrophotometer with an absorbance of $760 \mathrm{~nm}$ was used for readings. Leaf extracts were compared with a standard solution.

Extracts were obtained by consecutively submerging samples composed of approximately $1 \mathrm{~g}$ of dry milled leaves in three separate vials containing a $50 \%$ methanol solvent. The supernatants of each of the three vials were then allowed to evaporate, until $\sim 5 \mathrm{ml}$ of leaf extract per vial remained. A spectrophotometer with an absorbance of $760 \mathrm{~nm}$ was used for the readings. The readings from the leaf extracts were compared with a standard solution.

Data were analyzed using non-parametric Mann-Whitney tests, as the data were determined to assume a non-normal distribution. P-values were corrected with Bonferroni adjustments. The percentage data were analyzed using the $\chi^{2}$ test.

\section{RESULTS AND DISCUSSION}

Parameters associated with probing behavior and considered relevant are presented in Table 1. The number of probes and non-probing duration were similar for both cultivars (parameters 1 and 2). The time for probe initiation was also similar between the cultivars (parameter 3 ), but this parameter is not important to viral transmission.

The pathway phase (pattern "C", parameter 4) was shorter in the 'Pérola' cultivar, but this was most likely a consequence of other parameters, as

Table 1. Probing behavior parameters (means \pm standard error) of the Dysmicoccus brevipes pineapple mealybug on two cultivars.

\begin{tabular}{lcccc}
\hline \multicolumn{1}{c}{ Parameter } & Unit & $\begin{array}{c}\text { 'Smooth Cayenne' } \\
(\mathrm{n}=25)\end{array}$ & $\begin{array}{c}\text { 'Pérola' } \\
(\mathrm{n}=24)\end{array}$ & $\begin{array}{c}\text { Mann-Whitney test } \\
\text { p-value }\end{array}$ \\
\hline 1. Probe & $\mathrm{n}$ & $4.6 \pm 0.7$ & $4.5 \pm 0.8$ & 0.999 \\
2. Non-probing time & $\mathrm{h}$ & $3.1 \pm 0.5$ & $4.1 \pm 0.6$ & 0.183 \\
3. Time to the first probe & $\mathrm{h}$ & $1.1 \pm 0.4$ & $1.8 \pm 0.5$ & 0.040 \\
4. Pathway phase (pattern "C") & $\mathrm{h}$ & $7.5 \pm 0.7$ & $4.8 \pm 0.5$ & $0.004 *$ \\
5. Xylem phase (pattern "G") & $\mathrm{h}$ & $5.3 \pm 0.8$ & $7.0 \pm 0.9$ & 0.136 \\
6. Pathway + xylem phase & $\mathrm{h}$ & $12.8 \pm 0.5$ & $11.8 \pm 0.6$ & 0.234 \\
7. Mealybugs showing the phloem phase & $\%$ & 28.0 & 21.0 & $0.801\left(\chi^{2} \mathrm{p}\right.$-value with \\
8. Phloem phase (pattern "E") & $\mathrm{min}$ & $21.8 \pm 6.3(\mathrm{n}=7)$ & $20.2 \pm 14.1(\mathrm{n}=5)$ & 0.515 \\
9. Time to reach the phloem phase from the first probe & $\mathrm{h}$ & $7.7 \pm 1.2(\mathrm{n}=7)$ & $7.0 \pm 1.6(\mathrm{n}=5)$ & 0.626 \\
10. Time to reach the phloem phase in the probe & $\mathrm{h}$ & $4.5 \pm 1.1(\mathrm{n}=7)$ & $1.9 \pm 1.2(\mathrm{n}=5)$ & 0.074 \\
11. Hours until the phloem is reached & $\mathrm{h}$ & 8.5 & 8.9 & - \\
\hline
\end{tabular}

$\mathrm{n}=$ number of evaluated insects; * significant at $5 \%$, with the Bonferroni correction $(<0.006)$. 
the initial non-probing time (parameter 3), pathway phase (parameter 4) and xylem phase (parameter 5) are sequential events. The longer the time spent in one activity (i.e., one parameter), the less time available for the others. Thus, delays in the initiation of probing and the extended xylem phase were most likely responsible for the shorter pathway phase observed for insects on 'Pérola', and, therefore, the difference in pathway duration between the two cultivars was presumably a consequence of the other parameters, and did not reflect on differences in the stylet penetration.

The long xylem phase observed on both cultivars, lasting between $5 \mathrm{~h}$ and $7 \mathrm{~h}$ (parameter 5), was surprising. Xylem sap is composed mainly of water and mineral salts, with low nutritive compound contents. Thus, "drinking" in the xylem would only contribute to the insects water balance, and benefit only those insects experiencing water deficits (Spliller et al. 1990). Mealybugs feed on phloem sap, from which they obtain carbohydrates and other nutrients (Calatayud et al. 1994, Polania et al. 1999). No significant differences were found between the cultivars, when the pathway period and xylem phase were analyzed together (Table 1, parameter 6), confirming that the mealybug stylet penetration through plant tissues was similar for both cultivars.

Only a small number of mealybugs ( $28 \%$ for 'Smooth Cayenne' and $21 \%$ for 'Pérola') reached the phloem phase (pattern "E"), during the $16 \mathrm{~h}$ of recording (Table 1, parameter 7), and they remained in the phloem for a similar length of time (Table 1, parameter 8). In a study involving the cassava mealybug (Phenacoccus herreni Cox \& Williams), around $50 \%$ of the mealybugs reached the phloem phase, during 8-h EPG recording periods (Polania et al. 1999). The difference between this result and the one in the present study could be attributed to differences in the mealybug species and the plants involved. The time to reach the phloem, measured either from the first probe (Table 1, parameter 9) or from the probe that reached the phloem (Table 1, parameter 10), was also similar for both cultivars. Insects took approximately $9 \mathrm{~h}$, on average, to reach the phloem from the start of the experiment (Table 1, parameter 11), a longer time than other sucking insects (Powell et al. 2006). The small number of adult female mealybugs reaching the phloem phase and the short time spent in this phase indicated that adult females feed sparingly. The results also indicated that the nutritional reserves stored during the immature instar stages are large enough to sustain survival to adulthood and reproduction. Thus, it is possible that the phloem phase may be longer during the immature developmental stages.

Based on these results, it was concluded that the cultivars had no effect on the probing behavior of the pineapple mealybug in phloem and nonphloem tissues, and therefore could not account for the difference in their susceptibility to the PMWaV.

The phenolic contents of in vitro plants were similar in both cultivars (Table 2), what may help to explain the lack of differences in the mealybug probing behavior. However, other factors must be noted. These compounds are typically stored inside the vacuoles and within the cell wall matrix. In the cell wall, they are bound to sugars and form glycosides and amides, both of which are of low toxicity. When cell damage occurs, the toxicity of these compounds is activated via enzymatic hydrolysis (Matile 1984, Schoonhoven et al. 2005). Stylet penetration is primarily intercellular and the puncturing of cells is brief (20 s, on average; Santa-Cecília 2003), enabling the mealybugs to minimize their exposure to these toxic substances.

The effects of phenolic compounds in the cell wall on sucking insects, such as aphids, have been extensively examined. Solutes leaching into extracellular spaces and the level of subsequent ingestion required to affect the insect behavior must still be clarified. However, on the surface, cell wall phenolic compounds seem to be of only minor importance for plant resistance to insects (Rahbé et al. 1997).

Which phenolic compounds exist in the intercellular spaces is unknown, although there is some evidence that phenolic acids and flavonoids are present in extracellular fluids and in the phloem (Calatayud et al. 1994). Moreover, whether sucking insects can ingest intercellular fluids is either unknown or known to a very limited extent. Thus, the influence of phenolic compounds on the probing

Table 2. Phenolic concentrations ( $\mathrm{mg} 100 \mathrm{~g}^{-1}$ ) (means \pm standard error) in pineapple seedlings cultivated in vitro.

\begin{tabular}{lcc}
\hline Cultivar & Number of plants & Plants in vitro \\
\hline 'Smooth Cayenne' & 25 & $0.421 \pm 0.03$ \\
'Pérola' & 24 & $0.451 \pm 0.02$ \\
\hline
\end{tabular}

Mann-Whitney ( $\mathrm{p}=0.595)$. 
behavior of sucking insects remains uncertain, as does their concentrations inside the xylem and phloem, from where mealybugs ingest fluids (Leszczynski et al. 1985).

It was no possible to identify any factors in the non-phloematic and phloematic tissues that may influence the mealybug probing behavior in the tested cultivars. Similar patterns of mealybug development (Santa-Cecília et al. 2004) and probing behavior on both cultivars suggest that differences in wilt-disease resistance or tolerance must be related to intrinsic differences between cultivars and virus-plant interactions, rather than to variations in the mealybug feeding behavior.

The mealybug probing behavior was similar on both cultivars, and it seems to be no factors impeding mealybug probing in the pre-phloem or phloem tissues that could account for the difference in viral susceptibility between the 'Smooth Cayenne' and 'Pérola' cultivars. The data did not indicate an association between the phenolic compounds and probing behavior, as there were no differences in probing behavior, nor in the phenolic concentration of leaf tissues, between the cultivars produced in vitro.

Finally, it must be noted that young in vitro plants were used in these experiments because EPG signals could not be visualized in adult plants. Therefore, it is possible that phenolic concentrations could differ greatly in nature, where plants continuously face stress from the environment and tannins are produced to reduce tissue injuries.

\section{CONCLUSIONS}

1. No constraints on the mealybug stylet penetration or phloem-sap feeding were found on the 'Smooth Cayenne' and 'Pérola' cultivars that could account for the differences in susceptibility to the pineapple mealybug wilt-associated virus;

2. No significant differences in phenol contents were detected between the two cultivars.

\section{ACKNOWLEDGMENTS}

The authors thank the Fundação de Amparo à Pesquisa do Estado de Minas Gerais (Fapemig) and Conselho Nacional de Desenvolvimento Científico e Tecnológico (CNPq), for granting scholarships to the first and third authors, respectively.

\section{REFERENCES}

ASSOCIATION OF OFFICIAL ANALYTICAL CHEMISTS (AOAC). Official methods of analysis of the Association of Official Analytical Chemists. 15. ed. Washington, DC: AOAC, 1990.

CALATAYUD, P. A. et al. Electrically recorded feeding behaviour of cassava mealybug on host and non-host plants. Entomologia Experimentalis et Applicata, v. 72, n. 3, p. 219-232, 1994.

CID, M.; FERERES, A. Characterization of the probing and feeding behavior of Planococcus citri (Hemiptera: Pseudococcidae) on grapevine. Annals of the Entomological Society of America, v. 103, n. 3, p. 404-417, 2010.

CROMPTON, D. S.; ODE, P. J. Feeding behavior analysis of the soybean aphid (Hemiptera: Aphididae) on resistant soybean 'Dowling'. Journal of Economic Entomology, v. 103, n. 3, p. 648-653, 2010.

FERERES, A.; MORENO, A. Behavioural aspects influencing plant virus transmission by homopteran insects. Virus Research, v. 141, n. 2, p. 158-168, 2009.

GIACOMELLI, E. J.; PY, C. O abacaxi no Brasil. Campinas: Fundação Cargil, 1981.

GOLDSTEIN, J. L.; SWAIN, T. Changes in tannins in ripening fruits. Phytochemistry, v. 2, n. 4, p. 371-383, 1963.

GUNASHINGHE, U. B.; GERMAN, T. L. Purification and partial characterization of a virus from pineapple. Phytopathology, v. 79, n. 12, p. 1337-1341, 1989.

JAHN, G.; BEARDSLEY, J. W.; GONZÁLEZHERNÁNDEZ, H. A. Review of the association of ants with mealybug wilt disease of pineapple. Proceedings of the Hawaiian Entomological Society, v. 36, n. 1, p. 9-28, 2003.

KINDT, F.; JOOSTEN, N. N. F.; TJALLINGII, W. F. Electrical penetration graphs of thrips revised: combining DC- and AC-EPG signals. Journal of Insect Physiology, v. 52, n. 1, p. 1-10, 2006.

LAZZAROTTO, C. M.; LAZZARI, S. M. N.; PENTEADO, S. R. C. Feeding behavior of two exotic aphid species on their original hosts in a new invaded area. Neotropical Entomology, v. 40, n. 3, p. 316-321, 2011.

LESZCZYNSKI, B.; WARCHOL, J.; NIRAZ, S. The influence of phenolic compounds on the preference of winter wheat cultivars by cereals aphids. Insect Science and its Application, v. 6, n. 2, p. 157-158, 1985.

LIU, B. et al. Plant-mediated changes in the feeding behavior of an invasive whitefly. Environmental Entomology, v. 42, n. 5, p. 980-986, 2013. 
MATILE, P. Das toxische kompartiment der pflanzenzelle. Naturwissenschaften, v. 71, n. 1, p. 18-24, 1984.

MATOS, A. P. de; REINHARDT, D. H. Pineapple in Brazil: characteristics, research and perspectives. Acta Horticulture, v. 822, n. 1, p. 25-33, 2009.

MORAES, J. C. et al. Comportamento de prova do pulgão-verde Schizaphis graminum (Rond.) (Hemiptera: Aphididae) em plantas de trigo tratadas com silício e dimetoato. Bioscience Journal, v. 29, n. 1, p. 83-90, 2013.

MILES, P. W.; OERTLI, J. J. The significance of antioxidants in the aphid-plant interaction: the redox hypothesis. Entomologia Experimentalis et Applicata, v. 67, n. 3, p. 275-283, 1993.

MIRANDA, M. P. et al. Characterization of electrical penetration graphs of Bucephalogonia xanthophis, a vector of Xylella fastidiosa in citrus. Entomologia Experimentalis et Applicata, v. 130, n. 1, p. 35-46, 2009.

MORENO, A. et al. Differences in the mechanism of inoculation between a semi-persistent and a non-persistent aphid-transmitted plant virus. Journal of General Virology, v. 93 , n. 3, p. 662-667, 2012.

POLANiA, M. A.; CALATAYUd, P. A.; BELlOTTI, A. C. Comportamiento alimenticio del piojo harinoso Phenacoccus herreni (Sternorrhyncha: Pseudococcidae) e influencia del déficit hídrico en plantas de yuca sobre su desarrollo. Revista Colombiana de Entomologia, v. 25, n. 1-2, p. 1-9, 1999.

POWELL, G.; TOSH, C. R.; HARDIE, J. Host plant selection by aphids: behavioral, evolutionary, and applied perspectives. Annual Review of Entomology, v. 51, n. 1, p. 309-330, 2006.

RAHBÉ, Y. et al. Amino acids and proteins as cues in aphid-plant interactions. In: WALKER, G. P.; BACKUS, E. A. (Eds.). Principles and applications of electronic monitoring and other techniques in the study of Homopteran feeding behavior. Canberra: Thomas Say Publications in Entomology, 1997.

SANCHES, N. F. Manejo integrado da cochonilha do abacaxi. Cruz das Almas: Embrapa Mandioca e Fruticultura Tropical, 2005. (Abacaxi em foco, 35).
SANTA-CECÍLIA, L. V. C. Interação cochonilha (Pseudococcidae): planta avaliada mediante estudos biológicos e da técnica de "Electrical Penetration Graphs" (EPG). 2003. 84 f. Tese (Doutorado em Entomologia) Universidade Federal de Lavras, Lavras, 2003.

SANTA-CECÍLIA, L. V. C.; BUENO, V. H. P.; PRADO, E. Desenvolvimento de Dysmicoccus brevipes (Cockerell) (Hemiptera: Pseudococcidae) em duas cultivares de abacaxi. Ciência e Agrotecnologia, v. 28, n. 5, p. 10151020, 2004.

SANTA-CECÍLIA, L. V.C.; PRADO, E.; OLIVEIRA, M. S. Sobre o condicionamento alimentar na cochonilha-branca, Planococcus citri (Risso) (Hemiptera: Pseudococcidae). Revista Brasileira de Fruticultura, v. 35, n. 1, p. 86-92, 2013.

SCHOONHOVEN, L. M.; VAN LOON, J. J. A.; DICKE, M. Insect-plant biology. 2. ed. Oxford: Oxford University Press, 2005.

SETHER, D. M.; ULLMAN, D. E.; HU, J. S. Transmission of pineapple mealybug wilt-associated virus by two species by mealybug (Dysmicoccus spp.). Phytophatology, v. 88, n. 11, p. 1224-1230, 1998.

SPILLER, N. J.; KOENDERS, L.; TJALLINGII, W. F. Xylem ingestion by aphids: a strategy for maintaining water balance. Entomologia Experimentalis et Applicata, v. 55, n. 2, p. 101-104, 1990.

TJALLINGII, W. F. Electronic recording of penetration behaviour by aphids. Entomologia Experimentalis et Applicata, v. 24, n. 3, p. 521-530, 1978.

TJALLINGII, W. F. Comparison of AC and DC systems for electronic monitoring of stylet penetration activities by homopterans. In: WALKER, G. P.; BACKUS, E. A. (Eds.). Principles and applications of electronic monitoring and other techniques in the study of Homopteran feeding behaviour. Canberra: Thomas Say Publications in Entomology, 2000. p. 41-69.

TJALLINGII, W. F.; PRADO, E. Analysis of circulative ("virus") transmission by electrical penetration graphs. In: HARRIS, K. F.; SMITH, O. P.; DUFFUS, J. E. (Eds.). Virus-insect-plant interactions. New York: Academic Press, 2001. p. 69-85. 